\title{
Prevalence and correlates of sexual violence among adolescent girls and young women: findings from a cross-sectional study in a South African university
}

Anthony Idowu Ajayi ( $\square$ ajayianthony@gmail.com )

African Population and Health Research Center https://orcid.org/0000-0002-6004-3972

Elmon Mudefi

University of Fort Hare

Eyitayo Omolara Owolabi

Stellenbosch University

Research article

Keywords: sexual violence, alcohol use, family support, rape, South Africa

Posted Date: December 22nd, 2020

DOl: https://doi.org/10.21203/rs.3.rs-131818/v1

License: (1) This work is licensed under a Creative Commons Attribution 4.0 International License.

Read Full License

Version of Record: A version of this preprint was published at BMC Women's Health on August 16th, 2021. See the published version at https://doi.org/10.1186/s12905-021-01445-8. 


\section{Abstract}

Background: There is a window of opportunity to address the menace of sexual violence in South Africa, given the formation of the ministerial task team commissioned by the president in 2019 following the brutal rape and murder of a female university student in Cape Town. Epidemiological data on the prevalence and factors associated with sexual violence is critical to understanding the magnitude of the problem and designing interventions towards reversing the trend of sexual violence in the country. Drawing from cross-sectional data from a South Africa university, we examined the prevalence and correlates of sexual violence among adolescent girls and young women (AGYW).

Methods: We analysed data of 451 AGYW selected using stratified sampling. Sexual violence was defined as any sexual acts, and attempt to obtain a sexual act without consent. We used adjusted and unadjusted logistic regression models to examine the factors associated with exposure to sexual violence while controlling for relevant covariates.

Results: The lifetime and past year prevalence of sexual violence was $37.9 \%$ and $25.3 \%$, respectively. A higher prevalence of sexual violence was reported by heavy episodic drinkers of alcohol (lifetime $48.4 \%$ and past year $34.0 \%$ ), those who received insufficient financial support (lifetime $58.0 \%$ and past year $35.8 \%$ ) compared to non-users of alcohol and those who received adequate financial support. AGYW who reported heavy episodic use of alcohol were twice more likely to report experiencing sexual violence compared to non-users. However, individuals who received adequate family support were $76 \%$ and $65 \%$ less likely to report lifetime and past year experience of sexual violence compared to those who received inadequate family support. Also, AGYW who rated themselves as very religious were $80 \%$ and $75 \%$ less likely to report lifetime and past year experience of sexual violence compared to those who were not religious.

Conclusion: Our study shows that sexual violence affects a large proportion of girls, requiring intervention that not only focuses on increasing social support for survivors, facilitating reporting, and ensuring justice is served, but also target alcohol use reduction and poverty alleviation.

\section{Introduction}

Sexual violence is a significant and pervasive public health concern, yet scarcely reported to and investigated by appropriate authorities, especially in sub-Saharan Africa [1, 2]. It has several devastating mental, physical, social and somatic effects such as poor relationships with peers and increased psychological disorders like depression, anxiety, insomnia, post-traumatic stress disorder, self harm, poor academic performance, and physical disability [3-6]. Other adverse consequences of sexual violence include an increased likelihood of engaging in risky sexual behaviours and alcohol abuse as well as increased risk for sexually transmitted infections (STIs), including HIV/AIDS[7-9].

The majority of cases of sexual violence takes place before age 24 , and the first year of study is understood to be the most vulnerable year for sexual violence occurrence $[4,10]$, thus, making college 
campuses a high-risk environment and a significant and strategic place for interventions aimed at combating sexual violence $[11,12]$. Women are particularly at a higher risk, and at least one in five women experience sexual violence or assault during their college years $[1,13]$. Various individual-level factors such as multiple sexual partners[14], alcohol or substance abuse [4], prior history of victimisation $[4,15]$, and socio-economic status $[16,17]$ further contribute to the increasing burden of sexual violence. Also, institutional-level factors such as lack of effective policies and support for victims [13] foster the growing burden of sexual violence. Likewise, some traditions, such as the patriarchal practices, which portrays women as subordinates, also promote sexual violence and predispose women to higher risk [18, 19].

Although there seems to be an increasing sensitisation to this pressing problem across various countries, there is still a low rate of reporting. The weak justice system, shame, fear of not being believed, and social norms such as the "rape myth" are some of the factors that hinder proper reporting of incidences by victims [20,21]. Choo and Dunne[22] also implicated a low level of awareness of the various forms of sexual violence activities, especially the non-penetrative acts as another factor contributing to the low reportage of the incidence among the victims. Worryingly, the burden of sexual violence and the associated impacts are not well understood due to poor documentation and under-reporting and this, in turn, affects the development of effective measures and policies for combating the challenge [23, 24]. Unless the silence around sexual violence incidence is broken, the burden might linger for long [25].

South Africa is bedevilled with an exceedingly high rate of sexual violence [26]. The ineffective justicial structures in the country that have failed to deliver justice to many victims of sexual violence, which has, to some extent, worsen the problem [27], resulting in the low level of reporting [28]. Victims are often scared of the corrupt justice system and the possibility of re-traumatisation [28]. Naidoo and Moffat [28] further reiterated that only one out of nine cases of sexual violence gets reported, and there is a resultant promotion of a "rape culture," which leads to a form of acceptance of this odious act. Even though many cases of rape and brutal murder of young girls have received large media coverage, the recent brutal rape and killing of a young university girl in Cape Town shook the conscience of the nation, with the president personally attending her funeral. In response to this incidence, the South African government has organised a ministerial task committee for creating a support system for victims and ensuring justice is established. We are, however, unsure of how far-reaching this effort would be.

With regard to sexual violence across South African academic institutions, there seems to be a lack of adequate campus policies as well as a lack of adequate support systems for the victims [29]. Academic institutions across the country are in the process of enacting and implementing policies centred around awareness creation on sexual violence, ensuring justice for victims, providing support for victims, and ultimately reducing the burden of sexual violence [25], majority of which lacks relevant framework and are poorly implemented [30]. These efforts are better implemented in the presence of adequate data and the identification of contributing or associated factors. Reliable epidemiologic data is required for the formulation of evidence-based and effective policies to combat the menace at both the institution and the population level[$[7,31]$. This study therefore aimed at determining the prevalence and associated 
factors of sexual violence among adolescent girls and young women (AGYW) in one of the economicallydisadvantaged universities in South Africa. The findings of the study could help ascertain the magnitude of the burden, which in turn could inform better policy formulation and implementation of intervention strategies.

\section{Methods}

\section{Study Context and design}

We analysed data of a larger study that examined the individual and family-related factors that threaten the sexual health of adolescents and young adults (aged 17-24 years) [32,33]. This analysis is motivated by the recent national attention focusing on addressing sexual violence following the brutal rape and murder of a first-year student of the University of Cape Town. The study was conducted at a university campus in the Eastern Cape Province of South Africa between June and November 2018. The campus has a population of 6,000 students. This university was conveniently selected for this study as funds for a household survey was not available.

\section{Sampling and study procedure}

A total of 833 male and female students took part in the main study. The study sample size of 833 respondents was estimated using the MaCorr Sample Size Calculator, at $\pm 3.3 \%$ precision level, a 95\% confidence level, and a population of 6,000 students. To ensure representativeness, participants were selected using stratified sampling. Stratification was on the basis of sex, year and faculty of study. The parent study included more females than males, given that female student accounted for over $60 \%$ of students' population on campus. The samples selected in each year and faculty of study were proportionate to the size of these strata. For students to be eligible for this study, they have to be single and aged 24 years or below, and mentally capable to respond to the study questions. Eligible participants were recruited in their lecture room by trained research assistants and were asked to consent to the study after they have understood the purpose of the study and measures to protect their privacy, anonymity, and confidentiality. Questionnaires were self-administered in a private space earmarked for the study on campus and via the ODK application for android. Overall, 477 females completed the questionnaire. However, this analysis was limited to only 451 females participants ( $86.6 \%$ response rate) with complete responses to the outcome variable.

A sample of 451 is sufficient to yield $80 \%$ statistical power, at a \pm 4.6 precision, $95 \%$ confidence level and $50 \%$ maximum variation. The parent study collected self-reported information on HIV testing, knowledge and use of pre and post-exposure prophylaxes, condom use self-efficacy, sexual behaviours, contraceptive use, unintended pregnancy, abortion, contraceptive satisfaction, and sexual violence. Research assistants were explicitly trained for this study on how to use smartphones, with an open data kit (ODK) application, to administer questionnaire. A pilot survey with 30 students from nearby Walter Sisulu University was first carried out to validate and further improve the questionnaire. Before administering each questionnaire, research participants were first furnished with information about the 
purpose of the study, the process involved, and the use of findings. Ethical clearance was granted by the University of Fort Hare ethical review body. Only respondents who voluntarily accepted to participate in this study were interviewed after signing an informed consent form. Furthermore, researchers upheld all ethical research considerations that include confidentiality of provided information and anonymity of participants. Lastly, this study followed all the prescribed IRB guidelines for research when using human subjects.

\section{Measures}

\section{Dependent Variable}

The dependent variable for this study was sexual violence. We defined sexual violence as being forced to perform any sexual act, including being physically forced to have sexual intercourse or unwanted touching of genitals. Participants were asked whether or not they had ever experienced any form of sexual violence, if they did in the past year and if they did before they reached the age of 16 . Sexual violence was describe to them in the questionnaire as unwanted and inappropriate touching of genitalia, coerced sex and rape. Participants were required to select the dichotomously provided responses of either a 'Yes' or a 'No'. We also asked who the perpetrator was and whether they informed anyone about the incident.

\section{Independent Variables}

The independent variables included are demographic characteristics, such as age and parity, family factors such as family structure, living with parents and family support, and behavioural factors such as smoking tobacco products and alcohol and drug use. The selected variables are based on our review of the previous studies $[4,16,17]$. Age was measured as a continuous variable but later categorised as 19 years or less and 20-24 years. Parity was assessed by asking respondents how many children they have. We asked participants to select their family type from a list containing both parent family, singleparent family, and foster family. Also, participants were asked to rate the level of financial support they received from their family as "no support," "insufficient support," "moderate support," and adequate support. Family support in this study is a subjective measure of family wealth since AGYW may not be able to report their parental income accurately. By making them report on how they feel about the totality of the financial support they get from their parents and guardians, we are able to assess their socioeconomic vulnerability. After all, it is not so much of how much money a young person gets that determines if money could be used to influence their behaviour, but whether they consider the money sufficient. We further asked respondents if their mother and father are alive and whether they live with them. Alcohol use was categorised based on their' ever use, current use and 'never used' of alcohol. Also, we asked if respondents had ever smoked, currently smoke, and never smoked any tobacco products. Lastly, we asked if participants if they have ever and currently use drugs like cannabis, dagga, cocaine, and tik for recreational purposes. To ascertain drinking intensity among those who drink, we asked respondents to indicate the highest number of standard alcoholic drinks they have had on a single occasion-those who reported having had four or more standard alcoholic drinks were categorised as 
heavy drinkers, those who reported between one and three drinks were coded as moderate drinkers, and those never drank and non-users.

\section{Data Analysis}

Data analysis for this study was carried with the aid of the IBM Statistical Package for Social Sciences (SPSS) version 24.0. The analysis began with data cleaning to ensure that data entry errors were identified and removed. We then run descriptive statistics for all categorical variables to generate frequencies and percentages. We also fitted adjusted and unadjusted logistic regression to examine the relationship between exposure to sexual violence and demographic, behavioural and family characteristics. We assess if there were multicollinearity among the variables included in our models by estimating Pearson correlation for all variables of interests, and none of them was highly correlated. We coded and summarised the responses to the open-ended questions on the perpetrators.

\section{Results}

\section{Descriptive findings}

The analysis was restricted to 451 participants who answered the question on the outcome variable. Their average age was $21.03 \pm 1.61$ years. Most participants were aged 20 to 24 years $(79.6 \%)$, resided in the university residence (78.1\%), and ever used alcohol (66.5\%) (Table 1). Only a few of the participants received adequate family support (37.2\%), had at least one child (34.6\%), ever smoked cigarettes (28.2\%), and ever used drugs (30.8\%). 
Table 1

Demographical and behavioural characteristics of study participants

\begin{tabular}{|c|c|c|}
\hline Variables & Frequency & Percent \\
\hline \multicolumn{3}{|l|}{ Age (yrs) } \\
\hline $17-19$ & 92 & 20.4 \\
\hline $20-24$ & 359 & 79.6 \\
\hline \multicolumn{3}{|l|}{ Residence } \\
\hline University residence & 352 & 78.1 \\
\hline Off-campus residence & 64 & 14.2 \\
\hline Come from home & 35 & 7.8 \\
\hline \multicolumn{3}{|l|}{ Religiosity } \\
\hline Very religious & 98 & 21.6 \\
\hline Moderately religious & 197 & 43.7 \\
\hline Not religious & 156 & 21.7 \\
\hline \multicolumn{3}{|l|}{ Family structure } \\
\hline Single parent & 196 & 43.5 \\
\hline Both parents & 175 & 38.8 \\
\hline Live with grandparents & 49 & 10.9 \\
\hline Live with sister, uncle, brother, and aunt & 31 & 6.9 \\
\hline \multicolumn{3}{|l|}{ Family financial support } \\
\hline Adequate & 168 & 37.2 \\
\hline Moderate & 202 & 44.8 \\
\hline Insufficient & 78 & 17.3 \\
\hline No support & 3 & 0.7 \\
\hline \multicolumn{3}{|l|}{ Parity } \\
\hline No children & 295 & 65.4 \\
\hline At least one child & 156 & 34.6 \\
\hline \multicolumn{3}{|l|}{ Orphanhood status } \\
\hline Double orphan & 48 & 10.6 \\
\hline Single orphan & 147 & 32.6 \\
\hline
\end{tabular}




\begin{tabular}{|lll|}
\hline Variables & Frequency & Percent \\
\hline Both parents alive & 256 & 56.8 \\
\hline Living with parents & & \\
\hline Live with neither parents & 88 & 19.5 \\
\hline Live with either parents & 196 & 43.5 \\
\hline Live with both parents & 167 & 37.0 \\
\hline Ever drink alcohol & 300 & 66.5 \\
\hline Currently drink alcohol & 197 & 43.7 \\
\hline Drank last week & 108 & 24.0 \\
\hline Ever smoked cigarettes or other tobacco products & 127 & 28.2 \\
\hline Currently smoke tobacco products & 51 & 11.3 \\
\hline Ever used drugs & 138 & 30.8 \\
\hline Currently use drugs & 51 & 11.3 \\
\hline Sex after alcohol & 118 & 26.2 \\
\hline Childhood exposure to sexual violence & 80 & 17.7 \\
\hline
\end{tabular}

Lifetime and past-year prevalence of sexual violence were $37.9 \%(\mathrm{Cl} 33.4 \%-42.5 \%)$ and $25.2 \%(\mathrm{Cl}$ 21.3\%-29.6\%), respectively (Table 2). A higher prevalence was reported by heavy episodic drinkers of alcohol (lifetime $48.4 \%$ and past year $34.0 \%$ ), those who received insufficient financial support (lifetime $58.0 \%$ and past year $35.8 \%$ ) compare with non-users and those who received adequate financial support. 
Table 2

Lifetime and past year experience of sexual violence by background characteristics

\begin{tabular}{|c|c|c|c|c|}
\hline Variables & $\begin{array}{l}\text { Lifetime experience of } \\
\text { sexual violence }\end{array}$ & & $\begin{array}{l}\text { Past year experience of } \\
\text { sexual violence }\end{array}$ & $\begin{array}{l}P \text {. } \\
\text { value }\end{array}$ \\
\hline All & $171(37.9)$ & & $114(25.3)$ & \\
\hline \multicolumn{5}{|l|}{ Age (yrs) } \\
\hline $17-19$ & $30(32.6)$ & 0.240 & $20(21.7)$ & 0.381 \\
\hline $20-24$ & $141(39.3)$ & & $94(26.2)$ & \\
\hline \multicolumn{5}{|l|}{ Residence } \\
\hline $\begin{array}{l}\text { University } \\
\text { residence }\end{array}$ & $136(38.6)$ & 0.288 & $90(25.6)$ & 0.451 \\
\hline $\begin{array}{l}\text { Off campus } \\
\text { residence }\end{array}$ & $26(40.6)$ & & $18(28.1)$ & \\
\hline Come from home & $9(26.7)$ & & $6(17.1)$ & \\
\hline \multicolumn{5}{|l|}{ Family structure } \\
\hline Single parent & 73 (37.2) & 0.637 & $47(24.0)$ & 0.957 \\
\hline Both parents & $66(37.7)$ & & $46(26.3)$ & \\
\hline $\begin{array}{l}\text { Live with } \\
\text { grandparent }\end{array}$ & $17(34.7)$ & & $13(26.5)$ & \\
\hline $\begin{array}{l}\text { Live with sister and } \\
\text { uncles }\end{array}$ & $15(48.4)$ & & $8(25.8)$ & \\
\hline \multicolumn{5}{|l|}{$\begin{array}{l}\text { Family financial } \\
\text { support }\end{array}$} \\
\hline Adequate & $35(20.8)$ & $<0.001$ & $22(13.1)$ & $<0.001$ \\
\hline Moderate & $89(44.1)$ & & $63(31.2)$ & \\
\hline $\begin{array}{l}\text { Insufficient or no } \\
\text { support }\end{array}$ & $47(58.0)$ & & $29(35.8)$ & \\
\hline \multicolumn{5}{|l|}{ Parity } \\
\hline One or more & $70(44.9)$ & 0.027 & 49 (33.3) & 0.035 \\
\hline No children & $101(34.2)$ & & $65(24.4)$ & \\
\hline \multicolumn{5}{|l|}{ Ever used alcohol } \\
\hline Yes & $130(43.3)$ & 0.001 & $88(29.3)$ & 0.005 \\
\hline No & $41(27.2)$ & & $29(17.2)$ & \\
\hline
\end{tabular}




\begin{tabular}{|c|c|c|c|c|}
\hline Variables & $\begin{array}{l}\text { Lifetime experience of } \\
\text { sexual violence }\end{array}$ & & $\begin{array}{l}\text { Past year experience of } \\
\text { sexual violence }\end{array}$ & $\begin{array}{l}P \\
\text { value }\end{array}$ \\
\hline \multicolumn{5}{|l|}{ Ever used drug } \\
\hline Yes & $68(48.3)$ & 0.001 & $45(32.6)$ & 0.017 \\
\hline No & $103(32.9)$ & & $69(22.0)$ & \\
\hline \multicolumn{5}{|l|}{ Orphanhood status } \\
\hline Double orphan & $23(47.9)$ & 0.291 & $13(27.1)$ & 0.954 \\
\hline Single orphan & $56(38.1)$ & & $37(25.2)$ & \\
\hline Both parents alive & $92(35.9)$ & & $64(25.0)$ & \\
\hline \multicolumn{5}{|l|}{ Religiosity } \\
\hline Very religious & $16(16.3)$ & $<001$ & $8(8.2)$ & $\begin{array}{l}<.001 \\
0 .\end{array}$ \\
\hline $\begin{array}{l}\text { Moderately } \\
\text { religious }\end{array}$ & $78(39.1)$ & & $52(26.4)$ & \\
\hline Not Religious & $78(50.0)$ & & $54(34.6)$ & \\
\hline \multicolumn{5}{|l|}{$\begin{array}{l}\text { Alcohol use } \\
\text { intensity }\end{array}$} \\
\hline Heavy drinkers & $91(48.4)$ & $<.001$ & $64(34.0)$ & 0.001 \\
\hline Moderate drinkers & $39(34.8)$ & & $124(21.4)$ & \\
\hline Non-users & $41(27.2)$ & & $26(17.2)$ & \\
\hline
\end{tabular}

\section{Relationship between the survivors and the perpetrators}

We further examined how close the perpetrators of this act were to the victims and found that two-thirds of them had some sought of relationship with the perpetrator. Many of the survivors of sexual violence (39.5\%) did not mention the incidence to anyone since its occurrence (Table 3 ). 
Table 3

Relationship between the victims and the perpetrators

\begin{tabular}{|lll|}
\hline Variables & Frequency & Percent \\
\hline Who did it & & \\
\hline Boyfriend & 37 & 32.2 \\
\hline Uncle & 9 & 7.8 \\
\hline Cousin & 9 & 7.8 \\
\hline Stranger & 44 & 40.9 \\
\hline Causal friend & 16 & 13.9 \\
\hline Told anyone about the incidence & & \\
\hline Yes & 69 & 60.5 \\
\hline No & 45 & 39.5 \\
\hline
\end{tabular}

\section{Multivariate findings}

We used adjusted and unadjusted binary logistic regression models to examine the factors associated with exposure to sexual violence. The results of the unadjusted model, as presented in Table 4, indicate that adequate family support and being very religious were associated with lower odds of lifetime and past year exposure to sexual violence. However, parity, heavy episodic drinking alcohol, and drug use were significantly associated with a higher likelihood of having ever experienced sexual violence and exposure to sexual violence in the past year. In the adjusted model, adequate family support and religiosity remain protective against exposure to sexual violence, with individuals reporting adequate family support being $76 \%$ and $65 \%$ less likely to report lifetime and past-year exposure to sexual violence than those who received moderate or insufficient financial support. Likewise, heavy episodic drinking alcohol remains associated with a higher likelihood of lifetime and past year exposure to sexual violence in the adjusted model. However, the effect of drug use and parity were no longer significant. 
Table 4

Adjusted and unadjusted binary regression model showing predictors of lifetime exposure to sexual violence

\begin{tabular}{|c|c|c|c|c|}
\hline \multirow[t]{2}{*}{ Variables } & \multicolumn{2}{|c|}{ Life experience of sexual violence } & \multicolumn{2}{|c|}{$\begin{array}{l}\text { Past year experience of sexual } \\
\text { violence }\end{array}$} \\
\hline & $\begin{array}{l}\text { Unadjusted odds } \\
\text { ratio }\end{array}$ & $\begin{array}{l}\text { Adjusted odds } \\
\text { ratio }\end{array}$ & Unadjusted odds & Adjusted odds \\
\hline \multicolumn{5}{|l|}{ Age (yrs) } \\
\hline $17-19$ & $0.75(0.46-1.21)$ & $\begin{array}{l}1.02(0.59- \\
1.77)\end{array}$ & $0.78(0.45-1.36)$ & $\begin{array}{l}1.08(0.59- \\
1.98)\end{array}$ \\
\hline $20-24$ & 1 & 1 & 1 & 1 \\
\hline \multicolumn{5}{|l|}{$\begin{array}{l}\text { Family financial } \\
\text { support }\end{array}$} \\
\hline Insufficient & 1 & 1 & 1 & 1 \\
\hline Moderate & $0.57(0.34-0.96)^{\star}$ & $\begin{array}{l}0.67(0.38- \\
1.18)\end{array}$ & $0.81(0.47-1.40)$ & $\begin{array}{l}0.95(0.52- \\
1.71)\end{array}$ \\
\hline Adequate & $\begin{array}{l}0.19(0.11- \\
0.34)^{\star \star \star}\end{array}$ & $\begin{array}{l}0.24(0.13- \\
0.46)^{\star \star \star}\end{array}$ & $\begin{array}{l}0.27(0.14- \\
0.51)^{\star \star \star}\end{array}$ & $\begin{array}{l}0.35(0.17- \\
0.71)^{\star}\end{array}$ \\
\hline \multicolumn{5}{|l|}{ Family structure } \\
\hline Foster family & $1.12(0.66-1.91)$ & $\begin{array}{l}0.94(0.52- \\
1.70)\end{array}$ & $1.13(0.62-2.05)$ & $\begin{array}{l}1.00(0.52- \\
1.91)\end{array}$ \\
\hline Both parents family & $1.02(0.67-1.55)$ & $\begin{array}{l}1.32(0.75- \\
2.32)\end{array}$ & $1.13(0.71-1.81)$ & $\begin{array}{l}1.31(0.70- \\
2.45)\end{array}$ \\
\hline Single parent family & 1 & 1 & 1 & 1 \\
\hline \multicolumn{5}{|l|}{ Parity } \\
\hline $\begin{array}{l}\text { One or more } \\
\text { children }\end{array}$ & $1.56(1.05-2.32)^{\star}$ & $\begin{array}{l}1.27(0.81- \\
1.98)\end{array}$ & $\begin{array}{l}1.62(1.05- \\
2.51)^{\star}\end{array}$ & $\begin{array}{l}1.36(0.84- \\
2.20)\end{array}$ \\
\hline No children & 1 & 1 & 1 & 1 \\
\hline \multicolumn{5}{|l|}{ Religiosity } \\
\hline Very religious & $\begin{array}{l}0.20(0.10- \\
0.36)^{\star \star \star}\end{array}$ & $\begin{array}{l}0.31(0.16- \\
0.60)^{\star}\end{array}$ & $\begin{array}{l}0.17(0.08- \\
0.37)^{\star \star \star}\end{array}$ & $\begin{array}{l}0.25(0.11- \\
0.57)^{\star}\end{array}$ \\
\hline Moderately religious & $0.64(0.42-98)^{\star}$ & $\begin{array}{l}0.89(0.56- \\
1.43)\end{array}$ & $0.68(0.43-1.07)$ & $\begin{array}{l}0.87(0.54- \\
1.46)\end{array}$ \\
\hline Not Religious & 1 & 1 & 1 & 1 \\
\hline
\end{tabular}

***P-values $<0.001, *$ P-values $<0.05$ 


\begin{tabular}{|c|c|c|c|c|}
\hline \multirow{2}{*}{$\begin{array}{l}\text { Variables } \\
\text { Either parent dead }\end{array}$} & \multicolumn{2}{|c|}{ Life experience of sexual violence } & \multicolumn{2}{|c|}{$\begin{array}{l}\text { Past year experience of sexual } \\
\text { violence }\end{array}$} \\
\hline & $1.21(0.83-1.78)$ & $\begin{array}{l}1.07(0.61- \\
1.86)\end{array}$ & $1.03(0.67-1.59)$ & $\begin{array}{l}0.92(0.50- \\
1.71)\end{array}$ \\
\hline Both parents alive & 1 & 1 & 1 & 1 \\
\hline \multicolumn{5}{|l|}{ Drug use } \\
\hline Ever used drugs & $1.98(1.32-2.98)^{\star}$ & $\begin{array}{l}1.39(0.86- \\
2.25)\end{array}$ & $\begin{array}{l}1.71(1.10- \\
2.67)^{\star}\end{array}$ & $\begin{array}{l}1.16(0.69- \\
1.94)\end{array}$ \\
\hline Never used drugs & 1 & 1 & 1 & 1 \\
\hline \multicolumn{5}{|l|}{$\begin{array}{l}\text { Alcohol use } \\
\text { intensity }\end{array}$} \\
\hline Heavy drinker & $\begin{array}{l}2.52(1.59- \\
3.98)^{\star \star \star}\end{array}$ & $\begin{array}{l}1.86(1.07- \\
3.25)^{\star}\end{array}$ & $\begin{array}{l}2.48(1.48- \\
4.17)^{\star}\end{array}$ & $\begin{array}{l}2.03(1.10- \\
3.75)^{\star}\end{array}$ \\
\hline Moderate drinker & $1.43(0.84-2.43)$ & $\begin{array}{l}1.57(0.87- \\
2.81)\end{array}$ & $1.31(0.71-2.43)$ & $\begin{array}{l}1.47(0.76- \\
2.87)\end{array}$ \\
\hline Non users & 1 & 1 & 1 & 1 \\
\hline
\end{tabular}

\section{Discussion}

This study was motivated by the recent national attention to addressing sexual violence in South Africa following the brutal rape and murder of a first-year female student at University of Cape Town. Sexual violence often does not receive enough attention given that survivors hardly report the cases, even to friends or close confidants [34]. As such, relying on rape or sexual assault reporting will not provide accurate data on the prevalence of sexual violence among young people. We undertook this secondary analysis to determine the prevalence and associated factors of sexual violence among a cohort of AGYW. Our analysis showed that over a quarter of female students experience sexual violence in the past year and approximately two out five girls did in their lifetime. Overall, this finding highlights the tragic frequency at which young girls are exposed to sexual violence. A pooled analysis of the lifetime prevalence of sexual violence in South Africa academic institutions revealed a similar rate $(26.2 \%)$ to our study [35]. The observed prevalence in this study is higher than the global prevalence of $7.2 \%$ [36] and a prevalence of $17.4 \%$ in Southern Africa [36]. Another study conducted in another South African Province reported a $24.9 \%$ lifetime prevalence of sexual violence among women aged $18-49$ years [37]. Our reported prevalence is also higher than the $16.7 \%$ reported prevalence of sexual violence in the past year among Norwegian students [38]. Variations in the definition of sexual violence and the study contexts might explain the contrasting prevalence rates reported in these studies. It is well established that South Africa is confronted with an unacceptably high prevalence of sexual violence $[25,39,40]$, and our study further adds to this body of knowledge [34]. 
Consistent with previous studies [11, 41], our analysis shows that heavy episodic drinking was associated with an increased likelihood of exposure to sexual violence. Scholars have argued that the relationship between alcohol is bi-directional[42-44]. It has also been reported that male students buy alcoholic beverages for female students, pressuring them to drink above their limits and sexually abusing them when intoxicated [45]. The intoxication from alcohol could make individuals lose their agency, thereby subjecting them to rape or inappropriate and unwanted touching of genitals $[8,11]$. It also renders the victims powerless and unable to identify or interpret cues, negotiate or take an active decision in the face of such unpleasant incidence [46]. Also, victims of sexual violence may turn to alcohol to cope with the trauma of the incident [44]. Studies have shown that alcohol use and abuse is common among young people in South Africa $[47,48]$. Thus, the high prevalence of sexual violence could somewhat be attributed to the abuse of alcohol. As such, there is a need for stricter policies regarding the sales and commercialisation of alcohol and other harmful substances in and around college campuses to curb its consequential adverse effects such as sexual violence.

Notably, this study indicates that adequate family support is associated with a lower likelihood of exposure to sexual violence. As such, one could infer that adequate family support is protective against exposure to sexual violence. The pathway through which adequate family support reduces the odds of exposure to sexual violence could be understood through the vulnerability lens. The main needs of adolescents and young adults are material in nature, and money is required to meet these needs. Not getting enough money from home makes young people rate the level of support from their family as inadequate. Adequate family support means young people are not at the mercy of influential men who often lure vulnerable girls with material and monetary gifts, which increases the risk of exposure to sexual violence[16,17]. Our finding and explanation is consistent with previous studies that have established the link between poverty and sexual violence[49-51]. For example, the National Crime Victimisation Survey in the United States established that the poorest Americans are 12 times as likely as the wealthiest Americans to be exposed to sexual violence[49]. Given our finding on insufficient family support and exposure to sexual violence, it is paramount that any intervention being considered to tackle the menace of sexual violence must focus on addressing family and income vulnerabilities that predispose young people to sexual violence.

We also found a significant relationship between religiosity and lifetime and past year experience of sexual violence. In this study, religiosity was found to be protective against the experience of sexual violence. There are differing opinions on the impact of religion on sexual or intimate partner violence. While some scholars consider religion to be associated with positive health behaviours, including avoidance of alcohol or substance misuse and consequentially, reduction of sexual violence [52, 53], others have a contrary opinion. Religion, with or without cultural norms, is sometimes a guise under which victims and perpetrators hide or are hidden $[54,55]$. The findings in our study could be associated with the protective effect of religion on substance misuse and other positive health behaviours.

Our study established that close acquaintances were culprits of two-thirds of cases of sexual violence, and two-fifth of survivors did not mention the incidence to any one. These findings are important, 
especially in the era of "Me Too movement", where survivors are dismissed for not mentioning the incidence to no one. In fact, one of the greatest challenges of dealing with the burden of sexual violence is the silence around it[25]. Many victims find it difficult to report, and this has, in turn, led to less attention being paid to the matter. Several factors are responsible for this, and this includes the fact that many of the perpetrators are close acquaintances, which makes reporting difficult[56]. Living nearby and trust in the perpetrator, despite potentially being in danger, may play a role in higher victimisation [7]. Also, the fear of stigmatisation, shame, not being believed, and the gender-inequitable societal norms as well as the poor justice system, further reinforce this high rate of under-reporting of sexual violence cases [28]. This challenge could be more serious in academic institutions as students could find it difficult to report cases of sexual violence due to the fear of unknown consequences, both on their academic performances and generally in terms of risk of re-traumatisation and bullying. There is a need for an improved justice system and for the establishment of an effective support system that encourages victims to voice out without the fear of being penalised, stigmatised or ostracised, and that protects the victims. Also, universities need to put measures in place to control such acts on college campuses and even at the hall of residences to reduce this challenge.

\section{Strength and Limitations of the study}

Data for this study were collected from university students, who are more educated than the population of AGYW in the country. As such, the findings cannot be generalised across all South African AGYW. Also, given the sensitive nature of this topic, under-reporting of prevalence cannot be completely ruled out despite providing privacy during the data collection. Lastly, the association reported in this study cannot be construed as causation, given the cross-sectional nature of the data.

\section{Conclusion}

Our study shows that sexual violence occurs at a tragic frequency, requiring intervention that not only focuses on increasing social support for survivors, facilitating reporting, ensuring justice is served. Also, alcohol use and inadequate family support were associated with exposure to sexual violence. As such, alcohol use reduction and conditional cash transfer programmes for indigent AGYW are potentially relevant interventions.

\section{Declarations}

Competing interests- AIA is an associate editor with BMC Women's Health. Other authors have no conflict of interest to report.

Funding-We received no funding towards the completion of this work.

Availability of data-Data will be made available by the corresponding author upon request. 
Acknowledgements- Researchers acknowledge all study participants and research assistants, who provided their time to ensuring the collection of quality data. The authors also wish to acknowledge both the University of Fort Hare and the African Population and Health Research Centre for providing an enabling environment for the completion of this work.

Authors contributions- AIA conceptualised the study and performed the statistical analysis. AIA, EOO and EM contributed to results interpretation and drafting of the manuscript. All authors revised the manuscript and approved the final version.

Consent to publish- No applicable

Ethical consideration- Ethical clearance was granted by the University of Fort Hare ethical review body. Furthermore, researchers upheld all ethical research considerations that include confidentiality of provided information, informed consent and anonymity of participants. Lastly, this study followed all the prescribed IRB guidelines for research when using human subjects.

\section{References}

1. Cantor D, Fisher B, Chibnall SH, Townsend R, Lee H, Thomas G, et al. Report on the AAU campus climate survey on sexual assault and sexual misconduct. 2015.

2. Turner HA, Finkelhor D, Shattuck A, Hamby S. Recent victimization exposure and suicidal ideation in adolescents. Archives of pediatrics \& adolescent medicine. 2012;166(12):1149-54.

3. Daigle LE, Fisher BS, Cullen FT. The violent and sexual victimization of college women: Is repeat victimization a problem? Journal of interpersonal violence. 2008;23(9):1296-313.

4. Krebs CP, Lindquist $\mathrm{CH}$, Warner TD, Fisher BS, Martin SL. The differential risk factors of physically forced and alcohol-or other drug-enabled sexual assault among university women. Violence and Victims. 2009;24(3):302-21.

5. Krebs $\mathrm{CP}$, Lindquist $\mathrm{CH}$, Warner TD, Fisher BS, Martin SL. College women's experiences with physically forced, alcohol-or other drug-enabled, and drug-facilitated sexual assault before and since entering college. Journal of American College Health. 2009;57(6):639-49.

6. Daigneault I, Hébert M, McDuff P. Men's and women's childhood sexual abuse and victimization in adult partner relationships: A study of risk factors. Child abuse \& neglect. 2009;33(9):638-47.

7. Campbell R, Dworkin E, Cabral G. An ecological model of the impact of sexual assault on women's mental health. Trauma, Violence, \& Abuse. 2009;10(3):225-46.

8. McCauley JL, Ruggiero KJ, Resnick HS, Kilpatrick DG. Incapacitated, forcible, and drug/alcoholfacilitated rape in relation to binge drinking, marijuana use, and illicit drug use: A national survey. Journal of Traumatic Stress: Official Publication of The International Society for Traumatic Stress Studies. 2010;23(1):132-40.

9. Jordan CE, Combs JL, Smith GT. An exploration of sexual victimization and academic performance among college women. Trauma, Violence, \& Abuse. 2014;15(3):191-200. 
10. Cranney S. The relationship between sexual victimization and year in school in US Colleges: Investigating the parameters of the "red zone". Journal of interpersonal violence. 2015;30(17):313345.

11. Black M, Basile K, Breiding M, Smith S, Walters M, Merrick M, et al. National intimate partner and sexual violence survey: 2010 summary report. 2011.

12. Sinozich S LL. Rape and sexual assault victimization among college-age females, 1995-2013. Washington, D.C: Bureau of Justice Statistics, 2014.

13. Wiersma-Mosley JD, Jozkowski KN. A brief report of sexual violence among universities with NCAA Division I athletic programs. Behavioral Sciences. 2019;9(2):17.

14. Flack Jr WF, Hansen BE, Hopper AB, Bryant LA, Lang KW, Massa AA, et al. Some types of hookups may be riskier than others for campus sexual assault. Psychological trauma: theory, research, practice, and policy. 2016;8(4):413.

15. Kimmel MS, Kimmel MS. Guyland: The perilous world where boys become men: Harper New York; 2008.

16. Buhi ER, Clayton $\mathrm{H}$, Surrency HH. Stalking victimization among college women and subsequent helpseeking behaviors. Journal of American College Health. 2009;57(4):419-26.

17. Wiersma-Mosley JD, DiLoreto J. The role of Title IX coordinators on college and university campuses. Behavioral Sciences. 2018;8(4):38.

18. Bower C. The plight of women and children: Advancing South Africa's least privileged. The Annals of the American Academy of Political and Social Science. 2014;652(1):106-26.

19. Abeid M, Muganyizi P, Olsson P, Darj E, Axemo P. Community perceptions of rape and child sexual abuse: a qualitative study in rural Tanzania. BMC international health and human rights. 2014;14(1):23.

20. Finchilescu G, Dugard J. Experiences of gender-based violence at a South African university: prevalence and effect on rape myth acceptance. Journal of interpersonal violence. 2018:0886260518769352.

21. Gardner SK. Coming Out of the Sexual Harassment Closet: One Woman's Story of Politics and Change in Higher Education. NWSA Journal. 2009:171-95.

22. United Nations Joint Program on AIDS: : International center for AIDS care and treatment programs(ICAP).http://www.Unaids.org Columbia University's mailman School of Public Health.

23. Bagley CE, Natarajan P, Vayzman L, Wexler L, McCarthy S. Implementing Yale's sexual misconduct policy: The process of institutional change. Change: The Magazine of Higher Learning. 2012;44(2):715.

24. Wood L, Sulley C, Kammer-Kerwick M, Follingstad D, Busch-Armendariz N. Climate surveys: An inventory of understanding sexual assault and other crimes of interpersonal violence at institutions of higher education. Violence against women. 2017;23(10):1249-67. 
25. Treffry-Goatley A, De Lange N, Moletsane R, Mkhize N, Masinga L. What does it mean to be a young African woman on a university campus in times of sexual violence? A new moment, a new conversation. Behavioral Sciences. 2018;8(8):67.

26. Du Toit L. A phenomenology of rape: forging a new vocabulary for action. 2004.

27. Kapp C. Rape on trial in South Africa. The Lancet. 2006;367(9512):718-9.

28. Naidoo K. Rape in South Africa-a call to action. SAMJ: South African Medical Journal. 2013;103(4):210-1.

29. McCauley HL, Tancredi DJ, Silverman JG, Decker MR, Austin SB, McCormick MC, et al. Genderequitable attitudes, bystander behavior, and recent abuse perpetration against heterosexual dating partners of male high school athletes. American journal of public health. 2013;103(10):1882-7.

30. Joubert P, Van Wyk C, Rothmann S. The effectiveness of sexual harassment policies and procedures at higher education institutions in South Africa. SA Journal of Human Resource Management. 2011;9(1):1-10.

31. Akpotor J. Sexism and sexual harassment in tertiary institutions. Gender and Behaviour. 2013;11(1):5237-43.

32. Ajayi A, Mudefi E, Adeniyi O, Goon D. Achieving the first of the Joint United Nations Programme on HIV/AIDS (UNAIDS) 90-90-90 targets: understanding the influence of HIV risk perceptions, knowing one's partner's status and discussion of HIV/sexually transmitted infections with a sexual partner on uptake of HIV testing. International health. 2019;11(6):425-31.

33. Ajayi Al, Mudefi E, Yusuf MS, Adeniyi OV, Rala N, Ter Goon D. Low awareness and use of preexposure prophylaxis among adolescents and young adults in high HIV and sexual violence prevalence settings. Medicine. 2019;98(43).

34. Sigsworth R, Rapist ACBA. An Overview of Sexual Violence in South Africa. 2009.

35. Beyene AS, Chojenta C, Roba HS, Melka AS, Loxton D. Gender-based violence among female youths in educational institutions of Sub-Saharan Africa: a systematic review and meta-analysis. Systematic reviews. 2019;8(1):59.

36. Abrahams N, Devries K, Watts C, Pallitto C, Petzold M, Shamu S, et al. Worldwide prevalence of nonpartner sexual violence: a systematic review. The Lancet. 2014;383(9929):1648-54.

37. Steele SJ, Abrahams N, Duncan K, Woollett N, Hwang B, O'Connell L, et al. The epidemiology of rape and sexual violence in the platinum mining district of Rustenburg, South Africa: Prevalence, and factors associated with sexual violence. PloS one. 2019;14(7).

38. Sivertsen B, Nielsen MB, Madsen IE, Knapstad M, Lønning KJ, Hysing M. Sexual harassment and assault among university students in Norway: a cross-sectional prevalence study. BMJ open. 2019;9(6):e026993.

39. Mosavel M, Ahmed R, Simon C. Perceptions of gender-based violence among South African youth: implications for health promotion interventions. Health promotion international. 2012;27(3):323-30. 
40. Phipps A, Smith G. Violence against women students in the UK: Time to take action. Gender and Education. 2012;24(4):357-73.

41. Walsh K, Resnick HS, Danielson CK, McCauley JL, Saunders BE, Kilpatrick DG. Patterns of drug and alcohol use associated with lifetime sexual revictimization and current posttraumatic stress disorder among three national samples of adolescent, college, and household-residing women. Addictive behaviors. 2014;39(3):684-9.

42. Zinzow HM, Resnick HS, Amstadter AB, McCauley JL, Ruggiero KJ, Kilpatrick DG. Drug-or alcoholfacilitated, incapacitated, and forcible rape in relationship to mental health among a national sample of women. Journal of Interpersonal Violence. 2010;25(12):2217-36.

43. Lorenz K, Ullman SE. Alcohol and sexual assault victimization: Research findings and future directions. Aggression and Violent Behavior. 2016;31:82-94.

44. Testa M, Livingston JA. Alcohol consumption and women's vulnerability to sexual victimization: Can reducing women's drinking prevent rape? Substance use \& misuse. 2009;44(9-10):1349-76.

45. Dumbili EW, Williams C. "If she refuses to have sex with you, just make her tipsy": a qualitative study exploring alcohol-facilitated sexual violence against nigerian female students. Journal of interpersonal violence. 2017:0886260517708761.

46. Crowell N, Burgess A. Understanding violence against women. Washington, DC, US: American Psychological Association; 1996.

47. Owolabi EO, Ter Goon D, Adeniyi OV, Seekoe E. Adult binge drinking: rate, frequency and intensity in Buffalo City Metropolitan Municipality, South Africa. South African Family Practice. 2018;60(2):4652.

48. Vellios N, Van Walbeek C. Self-reported alcohol use and binge drinking in South Africa: Evidence from the National Income Dynamics Study, 2014-2015. South African Medical Journal. 2018;108(1):33-9.

49. Morgan RE, Kena G. Criminal victimization, 2018. Washington, USA: Bureau of Justice Statistics 2019.

50. Greco D, Dawgert S. Poverty and sexual violence: building prevention and intervention responses. 2007.

51. Bryant-Davis T, Ullman SE, Tsong Y, Tillman S, Smith K. Struggling to survive: Sexual assault, poverty, and mental health outcomes of African American women. American Journal of Orthopsychiatry. 2010;80(1):61.

52. Nicholas LJ. The association between religiosity, sexual fantasy, participation in sexual acts, sexual enjoyment, exposure, and reaction to sexual materials among black South Africans. Journal of Sex \& Marital Therapy. 2004;30(1):37-42.

53. Francis JM, Myers B, Nkosi S, Petersen Williams P, Carney T, Lombard C, et al. The prevalence of religiosity and association between religiosity and alcohol use, other drug use, and risky sexual behaviours among grade 8-10 learners in Western Cape, South Africa. PloS one. 2019;14(2):e0211322. 
54. Rabbani F, Qureshi F, Rizvi N. Perspectives on domestic violence: case study from Karachi, Pakistan. EMHJ-Eastern Mediterranean Health Journal, 14 (2), 415-426, 2008. 2008.

55. Fortune $M$, Enger $C$, editors. Violence against women and the role of religion. Applied Research Forum National Electronic Network on Violence Against Women USA: National Resource Centre on Domestic Violence; 2005.

56. Krebs CP, Lindquist CH, Warner TD, Fisher BS, Martin SL. Campus Sexual Assault (CSA) Study, Final Report (2007). 2016.

\section{Supplementary Files}

This is a list of supplementary files associated with this preprint. Click to download.

- ISSMSTROBEChecklist.pdf 